\begin{tabular}{l|l} 
Notaice & e-ISSN: 2655-9404 p-ISSN: 2721-8376 \\
DOI: 10.20473/ntr.v4i3.30136
\end{tabular}

Article history: Submitted 22 September 2021; Accepted 24 September 2021; Available online 1 October 2021.

\title{
Inkonsistensi Pengaturan Kewenangan Pembuatan Risalah Lelang oleh Notaris
}

\author{
Fatria Hikmatiar Al Qindy \\ alqindyfatria@gmail.com \\ Universitas Airlangga
}

\begin{abstract}
Notary is a general official authorized to make authentic deed, one of which is making the deed of auction document in accordance with the Notary Position Act, but in other provisions, the Auction Regulation states that the authorized to make the deed of auction is the Auction Officer which raises the issue of who is authorized to make the deed of the auction minutes. This study aims to find out the legal consequences if the notary makes the minutes of auction document and the authority of the notary in making the deed of the auction according to Law Number 2 of 2014 concerning Amendments to the Notary Position Act. This research is a normative research, the approach used is the legislation approach and conceptual approach. Based on the results of this study that the authorized to make the auction minutes is the Auction Officer not a Notary but the Notary can make the auction minutes if the notary concurrently serves as an Auction Officer, namely as Class II Auction Officer. Notary makes the deed of auction document in his capacity as an Auction Officer not as a Notary, then the legal consequence if the Notary makes the deed of auction document is the deed is null and void, the cancellation is done through the court and if any party is harmed by the deed, the Notary can be sued for an act against the law which is a compensation claim.
\end{abstract}

Keywords: Notary; Minutes of Auction; Auction Officer.

\section{Abstrak}

Notaris adalah pejabat umum yang berwenang untuk membuat akta autentik salah satunya adalah membuat akta risalah lelang sesuai dengan Undang-Undang Jabatan Notaris, namun dalam ketentuan lain yakni Peraturan Lelang menyebutkan bahwa yang berwenang membuat akta risalah lelang adalah Pejabat Lelang sehingga menimbulkan masalah siapakah yang berwenang untuk membuat akta risalah lelang. Penelitian ini bertujuan untuk mengetahui akibat hukum apabila notaris membuat akta risalah lelang dan kewenangan notaris dalam membuat akta risalah lelang menurut Undang-Undang Nomor 2 Tahun 2014 tentang Perubahan Undang-Undang Jabatan Notaris. Penelitian ini adalah penelitian normatif, pendekatan yang digunakan adalah pendekatan perundangundangan dan pendekatan konseptual. Berdasarkan hasil penelitian ini bahwa yang berwenang membuat risalah lelang adalah Pejabat Lelang bukan Notaris namun Notaris dapat membuat risalah lelang apabila notaris merangkap jabatan sebagai Pejabat Lelang yakni sebagai Pejabat Lelang Kelas II. Notaris membuat akta risalah lelang dalam kapasitasnya sebagai Pejabat Lelang bukan sebagai Notaris, kemudian akibat hukum apabila Notaris membuat akta risalah lelang adalah akta tersebut batal demi hukum yang pembatalannya dilakukan memalui pengadilan dan bila ada pihak yang dirugikan atas dibuatnya akta tersebut maka Notaris dapat digugat melakukan perbuatan melawan hukum yang merupakan gugatan ganti rugi.

Kata Kunci: Notaris; Risalah Lelang; Pejabat Lelang.

Copyright $\odot 2021$ Fatria Hikmatiar Al Qindy. 


\section{Pendahuluan}

Notaris merupakan salah satu dari cabang profesi tertua di dunia. Notaris adalah pejabat umum yang menjalankan profesi dalam memberikan jasa hukum kepada masyarakat. Notaris adalah pejabat umum yang berwenang untuk membuat akta autentik sejauh pembuatan akta autentik tertentu tidak dikhususkan bagi pejabat umum lainnya.

Notaris menurut Pasal 1 angka (1) Undang-Undang Nomor 2 Tahun 2014 tentang Perubahan Atas Undang-Undang Nomor 30 Tahun 2004 tentang Jabatan Notaris (selanjutnya di sebut UUJN) adalah "pejabat umum yang berwenang untuk membuat akta autentik dan memiliki kewenangan lainnya sebagaimana dimaksud dalam Undang-Undang ini atau undang-undang lainnya.

Kewenangan Notaris diatur dalam Pasal 15 UUJN, dimana ayat (1) Pasal tersebut menyatakan bahwa Notaris berwenang membuat semua akta otentik kecuali pembuatan akta itu sudah ditugaskan pada pejabat lain dan Pasal 15 ayat (2) huruf g UUJN menyatakan bahwa Notaris berwenang membuat akta risalah lelang.

Dengan diberikannya kewenangan tersebut kepada Notaris dalam hal pembuatan Akta Risalah Lelang sebagaimana disebutkan dalam ketentuan Pasal 15 ayat (2) huruf g UUJN, menyebabkan timbulnya ketidakpastian hukum dalam pelaksanaan pembuatan Akta Risalah Lelang oleh Notaris. Hal ini dikarenakan pemberian kewenangan tersebut tumpang tindih dengan kewenangan Pejabat Lelang sebagai pelaksana lelang yang diatur dalam Vendu Reglement (Peraturan Lelang), sebagaimana yang disebutkan di dalam Pasal 1a Vendu Reglement “penjualan di muka umum (lelang) tidak boleh diadakan kecuali di depan Juru Lelang (Pejabat Lelang)" dan Pasal 35 Vendu Reglement yang menyatakan "dari tiap penjualan di muka umum oleh Juru Lelang atau kuasanya, selama dalam penjualan, untuk tiap hari pelelangan atau penjualan dibuat berita acara (Risalah Lelang) tersendiri". Berdasarkan latar belakang masalah yang telah diuraikan diatas maka dapat dirumuskan permasalahan sebagai berikut, (1) Apakah Notaris berwenang membuat Akta Risalah Lelang menurut Undang-Undang Nomor 
2 Tahun 2014 tentang Perubahan UUJN padahal kewenangan pembuatan Akta Risalah Lelang sudah diberikan pada Pejabat Lelang; (2) Apakah akibat hukumnya apabila Notaris membuat Akta Risalah Lelang.

\section{Metode Penelitian}

Tipe penelitian yang digunakan untuk membahas permasalahan ini adalah tipe penelitian hukum normative, yaitu penelitian yang mengkaji studi dokumen, seperti peraturan perundang-undangan yang berhubungan dengan kewenangan Notaris dalam membuat Risalah Lelang dan akibat hukum Notaris yang membuat Risalah Lelang.

Dalam penyusunan tesis ini menggunakan pendekatan perundangundangan (Statute Approach), pendekatan konseptual (Conceptual Approach). Bahan hukum yang digunakan dalam menyusun penelitian ini terdiri dari bahan hukum primer, bahan hukum sekunder dan bahan hukum tersier.

Bahan Hukum Primer Bahan hukum yang bersifat mengikat dan mutlak dipergunakan untuk menyelesaikan permasalahan yang dikemukakan dalam tesis ini, yaitu berasal dari peraturan perundang-undangan dan peraturan lainnya yang terkait dengan kewenangan Notaris dalam membuat Risalah Lelang.

Bahan Hukum Sekunder Bahan hukum yang sifatnya menjelaskan bahan hukum primer, bahan hukum sekunder terdiri dari bahan hukum yang diperoleh dari literature maupun karya ilmiah lainnya yang bersifat pendukung. Sehingga dapat memberikan acuan dan memperluas alasan tentang apa yang dikemukakan pada tesis ini.

Bahan Hukum Tersier Bahan hukum yang memberikan petunjuk maupun penjelasan terhadap bahan hukum primer dan sekunder, seperti kamus.

Prosedur pengumpulan bahan hukum Prosedur pengumpulan bahan hukum yang digunakan oleh penulis adalah dengan cara mencari dan mengumpulkan bahan hukum yang terkait dengan permasalahan yang dibahas dalam penelitian ini. 


\section{Eksistensi Kewenangan Pembuatan Akta Risalah Lelang oleh Notaris}

Wewenang Notaris Secara Umum ada dalam Pasal 1 angka (1) UUJN, Notaris didefinisikan sebagai pejabat umum yang berwenang untuk membuat akta autentik dan kewenangan lainnya sebagaimana dimaksud dalam UUJN. Definisi yang diberikan oleh UUJN ini merujuk pada tugas dan wewenang yang dijalankan oleh notaris. Artinya notaris memiliki tugas sebagai pejabat umum dan memiliki wewenang untuk membuat akta autentik serta kewenangan lainnya yang diatur oleh UUJN. ${ }^{1}$

Melalui pengertian notaris tersebut terlihat bahwa tugas seorang notaris adalah menjadi pejabat umum, sedangkan wewenangnya adalah membuat akta autentik. Sedangkan akta autentik adalah suatu akta yang bentuknya ditentukan oleh undang-undang, dibuat oleh atau di hadapan pegawai-pegawai umum yang berkuasa untuk itu di tempat di mana akta dibuatnya. Akta notaris sebagai akta autentik dibuat menurut bentuk dan tata cara yang ditetapkan oleh UUJN. ${ }^{2}$

Sehubungan dengan wewenang notaris dalam menjalankan tugas jabatannya, notaris hanya diperbolehkan untuk melakukan jabatannya di dalam daerah tempat kedudukannya. Dengan demikian, notaris wajib mempunyai hanya satu kantor dan dengan hanya mempunyai satu kantor, berarti notaris dilarang mempunyai kantor cabang, perwakilan, dan/atau bentuk lainnya. Selain itu notaris tidak berwenang secara teratur menjalankan jabatannya di luar tempat kedudukannya. Artinya akta notaris sedapat-dapatnya dilangsungkan di kantor notaris kecuali pembuatan aktaakta tertentu. Apabila hal ini dilanggar, maka akta yang dibuat oleh notaris tersebut tidak autentik dan hanya mempunyai kekuatan sebagaimana akta di bawah tangan. ${ }^{3}$

Suatu akta yang dibuat oleh seorang pejabat tanpa ada wewenang dan tanpa ada kemampuan untuk membuatnya atau tidak memenuhi syarat, tidaklah dapat dianggap sebagai akta autentik, tetapi mempunyai kekuatan sebagai akta di bawah tangan apabila ditandatangani oleh pihak-pihak yang bersangkutan. ${ }^{4}$ 2009).[14].

${ }^{1}$ Abdul Ghofur Anshori, Lembaga Kenotariatan Indonesia, Perspektif Hukum Dan Etika (UII Press ${ }^{2}$ ibid.[5-6].

${ }^{3}$ R. Sugondo Notodisoeryo, Hukum Notaris Di Indonesia (PT Raja Grafindo Persada 1993).[9].

${ }^{4}$ Sudikno Mertokusumo, Hukum Acara Perdata Indonesia (Liberty 1998).[142-143]. 


\section{Wewenang Pembuatan Risalah Lelang}

Menurut Peraturan Menteri Keuangan Nomor 27/PMK.06/2016 tentang Petunjuk Pelaksanaan Lelang bahwa Risalah Lelang adalah "berita acara pelaksanaan lelang yang dibuat oleh Pejabat Lelang yang merupakan akta autentik dan mempunyai kekuatan pembuktian sempurna".

Risalah lelang sebagai suatu akta autentik, merupakan suatu bukti yang mengikat dalam arti apa yang ditulis di dalamnya harus dipercaya dan harus dianggap benar dan tidak memerlukan penambahan pembuktian. ${ }^{5}$

Risalah lelang memuat semua peristiwa yang terjadi dalam prosesi penjualan lelang sebagai bukti otentifikasi pelaksanaan lelang sebagaimana yang telah diatur dalam Pasal 35 Vendu Reglement dan kemudian ditegaskan dalam ketentuan Pasal 1 angka (35) Peraturan Menteri Keuangan Nomor 27/PMK.06/2016 tentang Petunjuk Pelaksanaan Lelang, yang antara lain berbunyi bahwa berita acara pelaksanaan lelang dibuat oleh Pejabat Lelang mempunyai kekuatan pembuktian (bewijskracht) yang sempurna (volledig, complete) bagi para pihak. ${ }^{6}$

Pasal 1 angka (1) Peraturan Menteri Keuangan Republik Indonesia Nomor 27/PMK.06/2016 tentang Petunjuk Pelaksanaan Lelang memberikan definisi lelang adalah "penjualan barang yang terbuka untuk umum dengan penawaran harga secara tertulis dan/atau lisan yang semakin meningkat atau menurun untuk mencapai harga tertinggi, yang didahului dengan pengumuman lelang".

Jenis lelang dibedakan berdasarkan sebab barang dijual dan penjual dalam hubungannya dengan barang yang akan dilelang. Sifat lelang ditinjau dari sudut sebab barang dilelang dibedakan antara Lelang Eksekusi dan Lelang Noneksekusi. Lelang Eksekusi adalah lelang untuk melaksanakan putusan/ penetapan pengadilan atau dokumen yang dipersamakan dengan itu sesuai dengan perundang-undangan yang berlaku. Lelang Noneksekusi adalah Lelang

\footnotetext{
${ }^{5}$ M. Yahya Harahap, Ruang Lingkup Permasalahan Eksekusi Bidang Perdata (Gramedia 1994).[433].

${ }^{6}$ Margono Dwi Susilo, 'Lelang Tanpa Risalah Lelang (Menafsirkan Kembali Pasal 35 Vendu Reglement)' (Kementerian Keuangan Republik Indonesia, 2018) <https://www.djkn.kemenkeu.go.id/ artikel/baca/12648/LELANG-TANPA-RISALAH-LELANG-MENAFSIRKAN-KEMBALI-PASAL35-VENDU-REGLEMENT.html> accessed 14 March 2018.
} 
selain Lelang eksekusi yang meliputi Lelang Noneksekusi wajib dan Lelang Noneksekusi sukarela. Sifat lelang ditinjau dari sudut penjual dalam hubungannya dengan barang yang akan dilelang, dibedakan antara Lelang yang sifatnya wajib, yang menurut peraturan perundang-undangan wajib melalui Kantor Lelang dan lelang yang sifatnya sukarela atas permintaan masyarakat. Lelang Noneksekusi Wajib adalah lelang untuk melaksanakan penjualan barang milik negara daerah dan kekayaan negara yang dipisahkan sesuai peraturan yang berlaku. Lelang Noneksekusi Sukarela adalah Lelang untuk melaksanakan kehendak perorangan atau badan untuk menjual barang miliknya. ${ }^{7}$

Menurut Peraturan Menteri Keuangan Nomor 27/PMK.06/2016 tentang Petunjuk Pelaksanaan Lelang bahwa Pejabat Lelang adalah orangyang berdasarkan peraturan perundang-undangan diberi wewenang khusus untuk melaksanakan penjualan barang secara lelang.

Pasal 3 ayat (1) dan (2) Vendu Reglement menyatakan bahwa Pejabat Lelang dibedakan dalam dua tingkatan, dimana Gubernur Jenderal menentukan orangorang dari golongan jabatan mana termasuk dalam masing-masing tingkat. Tingkatan dari Pejabat Lelang tersebut dijelaskan lebih lanjut dalam Pasal 7 Vendu Instructie yaitu:

1) Termasuk sebagai Pejabat Lelang Kelas I:

a) Pejabat Pemerintah yang diangkat khusus untuk itu.

b) Penerima uang Kas Negara, yang ditugaskan sebagai Pejabat Lelang.

2) Termasuk sebagai Pejabat Lelang Kelas II:

a) Pejabat negara, selain yang ditunjuk sebagai Pejabat Lelang Kelas I, yang menjabat pekerjaan yang diikatkan jabatan Pejabat Lelang.

b) Orang-orang yang khusus diangkat untuk jabatan ini.

Untuk penjelasan Pejabat Lelang Kelas II pada angka (2) Pasal di atas yakni orang-orang yang khusus diangkat untuk jabatan ini di jelaskan dalam Pasal 4 angka (3) Keputusan Menteri Keuangan Nomor 305/KMK.01/2002 tentang

${ }^{7}$ Purnama Tioria Sianturi, Perlindungan Hukum Terhadap Pembeli Barang Jaminan Tidak Bergerak Melalui Lelang (Mandar Maju Bandung 2008).[1]. 
Pejabat Lelang yang diubah dengan Keputusan Menteri Keuangan Nomor 451/ KMK.01/2002 yaitu:

1) Notaris;

2) Penilai;

3) Pensiunan Pegawai Negeri Sipil (PNS) Direktorat Jenderal Kekayaan Negara (DJKN) diutamakan yang pernah menjadi Pejabat Lelang Kelas I;

4) Lulusan Pendidikan dan Pelatihan Pejabat Lelang yang diselenggarakan Badan Pendidikan dan Pelatihan Keuangan (BPPK).

Dari penjelasan di atas dapat diketahui bahwa Notaris adalah salah satu dari orang-orang khusus yang dapat diangkat menjadi pejabat lelang. Dulu Pejabat Lelang ditunjuk, diangkat dan diberi wewenang untuk melakukan penjualan lelang oleh Gubernur Jenderal, sekarang pengangkatan dan pemberian wewenang tersebut oleh Direktur Jenderal Kekayaan Negara atas nama Menteri Keuangan.

Pejabat Lelang Kelas I berwenang melaksanakan lelang untuk semua jenis lelang atas permohonan Penjual sedangkan Pejabat Lelang Kelas II berwenang melaksanakan lelang Noneksekusi Sukarela atas Permohonan Balai Lelang atau Penjual. Balai Lelang adalah Badan Hukum Indonesia Berbentuk Perseroan Terbatas (PT) yang khusus didirikan untuk melakukan kegiatan usaha di bidang lelang. Penjual adalah orang, badan hukum atau badan usaha atau instansi yang berdasarkan peraturan perundang-undangan atau perjanjian berwenang untuk menjual barang secara lelang.

Dapat diketahui dari uraian di atas bahwa kewenangan pembuatan akta risalah lelang ada pada pejabat lelang, dan pejabat lelang tersebut dibagi menjadi 2 (dua) yakni Pejabat Lelang Kelas I dengan status pegawai negeri yang berwenang melaksanakan semua jenis lelang dan Pejabat Lelang Kelas II dengan status pegawai swasta yang salah satunya adalah Notaris yang berwenang hanya melaksanakan Lelang Noneksekusi Sukarela. Notaris dapat mempunyai kewenangan untuk membuat akta risalah lelang dengan cara merangkap jabatan menjadi Pejabat Lelang Kelas II, artinya Notaris membuat akta risalah lelang dalam kapasitasnya sebagai Pejabat Lelang bukan Notaris. 


\section{Notaris Sebagai Pejabat Lelang dalam Kaitan Pembuatan Risalah Lelang}

Notaris dalam menjalankan jabatannya sebagai Pejabat Lelang Kelas II dapat dimungkinkan, mengingat jabatan Notaris dan Jabatan sebagai Pejabat Lelang sepadan serta merupakan jabatan umum dan sesuai undang-undang dapat dibenarkan, di samping itu Notaris dan Pejabat Lelang sama-sama menghasilkan produk hukum yang disebut akta dan Risalah Lelang yang keduanya merupakan akta autentik.

Notaris dalam UUJN pasal 15 ayat (2) huruf g menyatakan notaris berwenang dalam membuat akta risalah lelang. Dari Undang-Undang tersebut notaris dapat membuat risalah lelang karena wewenang tersebut sudah di tentukan dalam UUJN.

Untuk dapat menjadi Pejabat Lelang Kelas II terdapat syarat yang harus di dilaksanakan, tidak terkecuali pada Notaris. Salah satunya pada Peraturan Menteri Keuangan Nomor 189/PMK.06/2017 tentang Pejabat Lelang Kelas II. Pasal 2 peraturan tersebut menyebutkan mengenai Pejabat Lelang Kelas II diangkat dan diberhentikan oleh Direktur Jenderal atas nama Menteri Keuangan dan Pasal 12 menyatakan harus memenuhi syarat diantaranya lulus pendidikan dan pelatihan untuk Pejabat Lelang Kelas II yang diselenggarakan oleh Badan Pendidikan dan Pelatihan Keuangan Kementerian Keuangan serta telah mengikuti praktik kerja (magang).

Wewenang Notaris untuk membuat akta risalah lelang dalam implementasinya tidak dapat langsung membuat akta risalah lelang karena dalam membuat akta risalah lelang oleh Notaris tidak otomatis Notaris dapat membuat akta risalah lelang, notaris harus dengan pengangkatan oleh Direktorat Jenderal Kekayaan Negara atas nama menteri keuangan dan harus mengikuti pendidikan dan pelatihan yang diselenggarakan oleh Kementerian Keuangan kemudian ada kewajiban untuk magang. Pasal 15 ayat (2) huruf g UUJN tidak secara otomatis dapat di laksanakan, namun harus disertai dengan ketentuan yang berlaku di kementerian keuangan. 


\section{Akibat Hukum Apabila Notaris Membuat Akta Risalah Lelang}

\section{Kekuatan Akta Notariil}

Akta Notaris adalah akta autentik yang memiliki kekuatan hukum dengan jaminan kepastian hukum sebagai alat bukti tulisan yang sempurna, tidak memerlukan tambahan alat pembuktian lain. ${ }^{8}$ Sehingga apa yang tertulis di dalamnya harus dianggap demikian adanya.

Menurut pendapat umum yang dianut pada setiap akta autentik demikian juga pada akta Notaris mempunyai 3 (tiga) kekuatan pembuktian yaitu: ${ }^{9}$

1. Kekuatan Pembuktian Lahiriah

Kemampuan lahiriah akta autentik merupakan kemampuan akta itu sendiri untuk membuktikan keabsahannya sebagai akta autentik jika dilihat dari luar atau lahirnya sebagai akta autentik serta sesuai dengan aturan hukum yang ditentukan mengenai syarat akta autentik maka akta tersebut berlaku sebagai akta autentik sampai terbukti sebaliknya artinya sampai ada yang membuktikan bahwa akta tersebut bukan akta autentik secara lahiriah. ${ }^{10}$

2. Kekuatan Pembuktian Formil

Akta Notaris harus memberikan kepastian bahwa suatu kejadian dan fakta tersebut dalam akta betul-betul dilakukan oleh Notaris atau diterangkan oleh pihak-pihak yang menghadap pada saat yang tercantum dalam akta sesuai dengan prosedur yang sudah ditentukan dalam pembuktian akta. Secara formal untuk membuktikan kebenaran dan kepastian tentang hari, tanggal, bulan, tahun, pukul atau waktu menghadap, dan identitas dari para pihak yang menghadap, paraf dan tanda tangan para pihak/penghadap, saksi dan Notaris, demikian juga tempat dimana akta itu dibuat, serta membuktikan apa yang dilihat, disaksikan, didengar oleh Notaris pada akta pejabat/berita acara dan mencatatkan keterangan atau pernyataan para pihak/penghadap pada akta pihak.

\footnotetext{
${ }^{8}$ A.A. Andi Prajitno, Apa Dan Siapa Notaris Di Indonesia (CV Perwira Media Nusantara 2015).[62].

${ }^{9}$ G.H.S. Lumban Tobing, Peraturan Jabatan Notaris (Peraturan Jabatan Notaris 1992).[55-59].

${ }^{10}$ Sudikno Mertokusumo, Mengenal Hukum Suatu Pengantar (Liberty 1999).[123].
} 
3. Kekuatan Pembuktian Material

Merupakan kepastian tentang materi suatu akta, karena apa yang tersebut dalam akta merupakan pembuktian yang sah terhadap pihak-pihak yang membuat akta atau mereka yang mendapatkan hak dan berlaku untuk umum, kecuali ada pembuktian sebaliknya keterangan atau pernyataan yang dituangkan/dimuat akta pejabat atau akta berita acara atau keterangan atau para pihak yang diberikan/disampaikan dihadapan Notaris akta pihak dan para pihak harus dinilai benar berkata yang kemudian dituangkan/ dimuat dalam akta berlaku sebagai yang benar atau setiap orang yang datang menghadap Notaris yang kemudian/keterangan dituangkan dan akta harus dinilai telah benar berkata. Apabila ternyata pernyataan/keterangan para penghadap tersebut menjadi tidak benar berkata maka hal tersebut tanggung jawab para pihak sendiri, Notaris terlepas dari hal semacam itu. Dengan demikian isi akta Notaris mempunyai kepastian sebagai yang sebenarnya menjadi bukti yang sah untuk/diantara para pihak dan para ahli waris serta penerima hak mereka.

Ketiga aspek tersebut diatas merupakan kesempurnaan akta Notaris sebagai akta autentik dan siapapun terikat oleh akta tersebut, jika dapat dibuktikan dalam suatu persidangan pengadilan, bahwa ada salah satu aspek tersebut tidak benar, maka akta yang bersangkutan hanya mempunyai kekuatan pembuktian sebagai akta dibawah tangan atau akta tersebut didegradasikan dalam kekuatan pembuktiannya sebagai akta yang mempunyai kekuatan pembuktian sebagai akta dibawah tangan. ${ }^{11}$

\section{Kewenangan Membuat Akta Risalah Lelang oleh Pejabat Lelang}

Pembuatan akta Risalah Lelang merupakan wewenang dari Pejabat lelang, hal ini sesuai dengan bunyi Pasal 1 angka (35) Peraturan Menteri Keuangan Nomor 27/PMK.06/2016 tentang Petunjuk Pelaksanaan Lelang yang berbunyi “Risalah

\footnotetext{
11 Sjaifurrachman dan Habib Ajie, Aspek Pertanggungjawaban Notaris Dalam Pembuatan Akta (CV Mandar Maju 2011).[118].
} 
Lelang adalah berita acara pelaksanaan lelang yang dibuat oleh Pejabat Lelang yang merupakan akta autentik dan mempunyai kekuatan pembuktian sempurna".

Kewenangan tersebut di pertegasan di dalam Vendu Reglement (Peraturan Lelang) pada Pasal 1a dan Pasal 35. Pasal 1a berbunyi “Penjualan di muka umum tidak boleh diadakan kecuali di depan juru lelang” dan Pasal 35 berbunyi “Dari tiap penjualan di muka umum oleh juru lelang atau kuasanya, selama dalam penjualan, untuk tiap hari pelelangan atau penjualan dibuat berita acara tersendiri".

Dari kedua penjelasan di atas dapat diketahui bahwa yang berwenang untuk membuat akta Risalah Lelang adalah Pejabat Lelang karena telah di atur di dalam Vendu Reglement dan Peraturan Menteri Keuangan Nomor 27/PMK.06/2016 tentang Petunjuk Pelaksanaan Lelang.

Pejabat Lelang dan Notaris sama-sama merupakan pejabat umum, keduanya di tugaskan untuk membuat akta autentik. Pejabat Lelang khusus membuat akta autentik berupa akta risalah lelang sedangkan notaris membuat semua akta autentik asalkan belum ada pejabat lain yang di tugaskan untuk membuat akta tersebut, jadi kewenangan notaris lebih luas dari pada pejabat lelang, namun sekalipun lebih luas, Notaris tidak berwenang membuat akta risalah lelang karena merupakan tugas pejabat lelang yang diatur didalam Vendu Reglement.

\section{Akibat Hukum Risalah Lelang yang dibuat Oleh Notaris}

Di dalam UUJN tidak di atur mengenai akibat hukum apabila Notaris membuat akta risalah lelang. Notaris tidak berwenang membuat akta risalah lelang karena wewenang pembuatan akta risalah lelang ada pada Pejabat Lelang berdasarkan Vendu Reglement (Peraturan Lelang), sehingga apabila Notaris membuat akta Risalah Lelang maka akta yang dibuatnya tersebut menjadi tidak sah karena mengandung cacat hukum yakni melawan ketentuan Pasal 15 ayat (1) UUJN yang menjelaskan bahwa Notaris berwenang membuat semua akta autentik sepanjang tidak ditugaskan kepada pejabat lain, sementara kewenangan tersebut sudah ditugaskan pada Pejabat Lelang sehingga Notaris menjadi tidak berwenang untuk membuat akta risalah lelang. 
Wewenang Notaris dalam pembuatan akta autentik sepanjang tidak dikecualikan kepada pihak atau pejabat lain, atau Notaris juga berwenang membuatnya disamping dapat dibuat oleh pihak atau pejabat lain, mengandung makna bahwa wewenang Notaris dalam membuat akta autentik mempunyai wewenang yang umum, sedangkan pihak lainnya mempunyai wewenang terbatas. Pasal 15 UUJN, telah menentukan wewenang Notaris. Wewenang ini merupakan suatu batasan, bahwa Notaris tidak boleh melakukan suatu tindakan di luar wewenang tersebut.

Risalah Lelang merupakan akta autentik yang mempunyai nilai pembuktian sempurna. Untuk dapat dikatakan sebagai akta autentik maka akta tersebut harus memenuhi syarat yang terdapat di dalam Pasal 1868 Burgelijk Wetboek yang berbunyi "Suatu akta autentik adalah suatu akta yang dalam bentuk yang ditentukan oleh undang-undang dibuat oleh atau di hadapan pejabat umum yang berkuasa untuk itu ditempat dimana akta itu dibuat".

Dari bunyi pasal diatas dapat disimpulkan bahwa untuk memenuhi klasifikasi sebagai akta autentik maka suatu akta harus memenuhi syarat-syarat sebagai berikut: ${ }^{12}$

1. Akta itu harus dibuat oleh atau di hadapan seorang pejabat umum;

2. Akta itu harus dibuat dalam bentuk yang ditentukan oleh undang-undang;

3. Pejabat umum sebagaimana dimaksud harus mempunyai wewenang untuk membuat akta itu.

Apabila Notaris membuat akta Risalah Lelang maka akta risalah lelang yang dibuatnya bukan merupakan akta autentik karena tidak memenuhi syarat-syarat sebagai akta autentik. Syarat yang tidak terpenuhi adalah syarat yang terakhir yakni "Pejabat umum oleh atau di hadapan siapa akta itu dibuat, harus mempunyai wewenang untuk membuat akta tersebut". Notaris tidak berwenang membuat akta risalah lelang karena ada pejabat lain yang ditunjuk khusus untuk membuat akta risalah lelang yakni pejabat lelang, sehingga apabila notarismembuat akta

${ }^{12}$ Salim HS, Teknik Pembuatan Akta Satu (PT Raja Grafindo Persada 2015).[28]. 
risalah lelang maka akta tersebut tidak mempunyai nilai pembuktian sempurna layaknya akta autentik.

Akta risalah lelang yang dibuat oleh notaris batal atau batal demi hukum atau mempunyai kekuatan pembuktian sebagai akta dibawah tangan terjadi karena tidak dipenuhinya syarat-syarat yang sudah diatur menurut hukum, tanpa perlu adanya tindakan hukum tertentu dari yang bersangkutan yang berkepentingan. Sehingga bersifat pasif. Oleh karena itu, kebatalan bersifat pasif, artinya tanpa ada tindakan aktif atau upaya apapun para pihak yang terlibat dalam suatu perjanjian, maka akan batal atau batal demi hukum karena secara sertamerta ada syaratsyarat yang tidak dipenuhi. ${ }^{13}$

Berdasarkan penelusuran isi tiap pasal didalam UUJN, tidak ditegaskan akta yang dikualifikasikan sebagai akta yang mempunyai kekuatan pembuktian di bawah tangan dan akta yang batal demi hukum dapat diminta ganti kerugian kepada Notaris berupa penggantian biaya, ganti rugi dan bunga. Hal ini dapat ditafsirkan akta Notaris terdegradasi mempunyai kekuatan pembuktian sebagai akta di bawah tangan dan akta Notaris yang batal demi hukum keduanya dapat dituntut penggantian biaya, ganti rugi dan bunga, hanya ada satu pasal, yaitu Pasal 52 ayat (3) UUJN yang menegaskan, bahwa akibat akta yang mempunyai kekuatan pembuktian sebagai akta di bawah tangan, Notaris wajib membayar biaya, ganti rugi dan bunga. ${ }^{14}$

Penggantian biaya, ganti rugi atau bunga dapat dituntut terhadap Notaris harus didasarkan pada suatu hubungan hukum antara Notaris dengan para pihak yang menghadap Notaris. Jika ada pihak yang merasa dirugikan sebagai akibat langsung dari suatu akta Notaris, maka yang bersangkutan dapat menuntut secara perdata terhadap Notaris. ${ }^{15}$

Salah satu sebab akta risalah lelang yang dibuat oleh Notaris mejadi cacat hukum dan batal adalah perbuatan melawan hukum. Perbuatan melawan hukum merupakan perbuatan yang menimbulkan kerugian, dan secara normatif perbuatan

${ }^{13}$ Habib Adjie, Kebatalan Dan Pembatalan Akta Notaris (PT Refika Aditama 2011).[67].

14 ibid.[80].

${ }^{15}$ Habib Adjie, Sanksi Perdata Dan Administratif Terhadap Notaris Sebagai Pejabat Publik (PT Refika Aditama 2017).[91]. 
tersebut tunduk pada ketentuan Pasal 1365 Burgelijk Wetboek ${ }^{16}$ yang berbunyi: Tiap perbuatan yang melawan hukum dan membawa kerugian kepada orang lain, mewajibkan orang yang menimbulkan kerugian itu karena kesalahannya untuk menggantikan kerugian tersebut.

Bentuk tanggung gugat yang dianut oleh Pasal 1365 ini adalah tanggung gugat berdasarkan kesalahan. Hal ini dapat dilihat dalam ketentuan pasal tersebut yang mensyaratkan adanya kesalahan pada pelaku untuk sampai pada keputusan apakah perbuatan seseorang itu merupakan perbuatan melawan hukum. ${ }^{17}$

Perbuatan melawan hukum oleh Notaris, tidak hanya perbuatan yang langsung melawan hukum, melainkan juga perbuatan yang secara langsung melawan peraturan lain, seperti Notaris jika membuat akta risalah lelang berarti melawan peraturan lelang. Dalam kasus ini, maka terhadap Notaris yang aktanya cacat hukum, maka Notaris yang bersangkutan telah menyalahi ketentuan UUJN atau ketentuan Peraturan Lelang. ${ }^{18}$

Dari uraian di atas dapat diketahui bahwa apabila Notaris membuat akta risalah lelang maka akibat hukumnya adalah akta yang dibuatnya menjadi batal demi hukum karena pembuatan akta tersebut bukan merupakan kewenangannya melainkan kewenangan pejabat lelang. Notaris yang membuat akta risalah lelang telah melampaui batas kewenangannya sebagai Notaris dalam pembuatan akta. Pembatalan akta tersebut didasarkan pada putusan pengadilan yang telah mempunyai kekuatan hukum tetap. Apabila ada pihak yang dirugikan atas dibuatnya akta tersebut maka Notaris dapat digugat melakukan perbuatan melawan hukum yang merupakan gugatan ganti rugi.

\section{Tanggungjawab Notaris yang Membuat Risalah Lelang}

Akta risalah lelang merupakan akta autentik yang dibuat oleh pejabat umum. Notaris dan Pejabat Lelang sama-sama merupakan pejabat umum

\footnotetext{
${ }^{16}$ Sjaifurrachman dan Habib Ajie (n 11)., Op. Cit., [179].

${ }^{17}$ ibid.

18 ibid.[179-180].
} 
yang berwenang untuk membuat akta autentik. Pembuatan akta risalah lelang merupakan kewenangan dari pejabat lelang sehingga Notaris tidak berwenang membuat akta tersebut. Apabila Notaris membuat akta risalah lelang maka ia harus bertanggungjawab atas akibat akta yang dibuatnya karena pembuatan akta tersebut bukan kewenangannya melainkan kewenangan dari pejabat lelang yang mengakibatkan akta yang dibuatnya menjadi cacat hukum dan tidak bisa dikatakan sebagai akta autentik.

Tanggung gugat terhadap Notaris timbul karena adanya kesalahan yang dilakukan didalam menjalankan tugas jabatan dan kesalahan itu menimbulkan kerugian bagi orang yang minta jasa pelayanan (klien) Notaris. Dengan bahasa yang sederhana dapat dikatakan bahwa setiap tugas atau kewajiban yang didasarkan atas kewenangan yang sah baik yang bersumber dari undang-undang maupun dari perjanjian dapat menimbulkan tanggung jawab pada si pelaksana tugas atau kewajiban itu. setiap pemberian atau adanya suatu kewenangan senantiasa diikuti pula dengan kewajiban dan/atau tanggung jawab dari padanya. Oleh karena Notaris diberi kewenangan membuat akta autentik, maka Notaris yang bersangkutan berkewajiban untuk memenuhi segala persyaratan yang telah ditentukan, khususnya dalam pembuatannya agar akta yang dibuat itu memenuhi syarat sebagai akta autentik yang sah. ${ }^{19}$

Apabila akta autentik dalam pembuatannya cacat hukum yang sematamata disebabkan oleh kesalahan dari Notaris dan kemudian akta itu oleh Pengadilan dinyatakan tidak autentik, atau tidak sah, atau menjadi batal demi hukum atau terdegradasi menjadi akta dibawah tangan, maka Notaris yang bersangkutan harus bertanggung gugat atas kesalahan yang ditimbulkan karena kecorobohannya.

Apabila ada akta autentik yang mengandung cacat yuridis dalam pembuatannya, maka Notaris yang bersangkutan harus bertanggung jawab pada kliennya. Bentuk tanggung jawab terhadap klien bisa berupa pemberian ganti rugi

${ }^{19}$ ibid.[17]. 
sepanjang klien yang bersangkutan terbukti menderita kerugian yang disebabkan adanya kesalahan yang telah dibuat oleh Notaris itu. ${ }^{20}$

PertanggungjawabanNotaristimbulkarenaadanyakesalahanyangdilakukan di dalam menjalankan suatu tugas jabatan dan kesalahan itu menimbulkan kerugian bagi orang lain yang minta jasa pelayanan (klien) Notaris, artinya untuk menetapkan seorang Notaris bersalah yang menyebabkan penggantian biaya, ganti rugi dan bunga, disyaratkan bilamana perbuatan melawan hukum dari Notaris tersebut dapat dipertanggungjawabkan, dan pertanggungjawaban tersebut dapat dilihat dari sudut pandang keperdataan dan administrasi. ${ }^{21}$

Dari uraian di atas dapat diketahui apabila Notaris membuat akta risalah lelang maka ia harus bertanggungjawab karena kesalahannya tersebut. Bentuk tanggung jawabnya berupa sanksi terhadap Notaris. Bentuk sanksinya dapat berupa sanksi perdata dan sanksi administrasi.

\section{Kesimpulan}

Notaris tidak berwenang membuat akta risalah lelang karena ada pejabat lain yang telah ditunjuk untuk membuat akta risalah lelang yaitu Pejabat Lelang. Apabila Notaris ingin membuat akta risalah lelang maka ia harus menjadi pejabat lelang yakni dengan cara merangkap jabatan sebagai Pejabat Lelang dan pembuatan akta tersebut dilakukan dalam kapasitasnya sebagai Pejabat Lelang bukan Notaris. Apabila Notaris membuat akta risalah lelang maka akibat hukumnya akta tersebut batal demi hukum karena pembuatan akta tersebut bukan kewenangan Notaris. Pembatalannya dilakukan melalui pengadilan dan bila ada pihak yang dirugikan atas dibuatnya akta tersebut maka Notaris dapat digugat melakukan perbuatan melawan hukum yang merupakan gugatan ganti rugi.

\footnotetext{
20 ibid.[17-18].

${ }^{21}$ ibid.[33].
} 


\section{Daftar Bacaan}

\section{Buku}

A.A. Andi Prajitno, Apa Dan Siapa Notaris Di Indonesia (CV Perwira Media Nusantara 2015).

Abdul Ghofur Anshori, Lembaga Kenotariatan Indonesia, Perspektif Hukum Dan Etika (UII Press 2009).

Ajie S dan H, Aspek Pertanggungjawaban Notaris Dalam Pembuatan Akta (CV Mandar Maju 2011).

G.H.S. Lumban Tobing, Peraturan Jabatan Notaris (Peraturan Jabatan Notaris 1992).

Habib Adjie, Sanksi Perdata Dan Administratif Terhadap Notaris Sebagai Pejabat Publik (PT Refika Aditama).

- - , Kebatalan Dan Pembatalan Akta Notaris (PT Refika Aditama 2011).

M. Yahya Harahap, Ruang Lingkup Permasalahan Eksekusi Bidang Perdata (Gramedia 1994).

Purnama Tioria Sianturi, Perlindungan Hukum Terhadap Pembeli Barang Jaminan Tidak Bergerak Melalui Lelang (Mandar Maju 2008).

R. Sugondo Notodisoeryo, Hukum Notaris Di Indonesia (PT Raja Grafindo Persada 1993).

Salim HS, Teknik Pembuatan Akta Satu (PT Raja Grafindo Persada 2015).

Sudikno Mertokusumo, Hukum Acara Perdata Indonesia (Liberty 1998).

- -, Mengenal Hukum Suatu Pengantar (Liberty 1999).

\section{Laman}

Margono Dwi Susilo, 'Lelang Tanpa Risalah Lelang (Menafsirkan Kembali Pasal 35 Vendu Reglement)' (Kementerian Keuangan Republik Indonesia, 2018). <https://www.djkn.kemenkeu.go.id/artikel/baca/12648/LELANGTANPA-RISALAH-LELANG-MENAFSIRKAN-KEMBALI-PASAL-35VENDU-REGLEMENT.html> accessed 14 March 2018.

How to cite: Fatria Hikmatiar Al Qindy, 'Inkonsistensi Pengaturan Kewenangan Pembuatan Risalah Lelang oleh Notaris' (2021) Vol. 4 No. 3 Notaire. 
372 | Fatria Hikmatiar: Inkonsistensi Pengaturan Kewenangan...

--Halaman ini sengaja dikosongkan-- 